\title{
ANALISIS KESALAHAN MAHASISWA DALAM MEMECAHKAN MASALAH MATEMATIKA BERDASARKAN ANALISIS NEWMAN DITINJAU DARI GENDER
}

\author{
Ririn Dwi Agustin \\ IKIP Budi Utomo Malang \\ ririndwiagustin85@gmail.com
}

\begin{abstract}
Abstrak
Kesulitan dalam pembelajaran di kelas menyebabkan mahamahasiswa program studi pendidikan matematika melakukan kesalahan dalam memecahkan masalah matematika. kesalahan tersebut dilakukan baik oleh mahamahasiswa laki-laki maupun mahamahasiswa perempuan. Pada mata kuliah struktur aljabar merupakan salah satu materi yang membutuhkan prosedur yang tepat dalam penyelesaiannya. Penelitian ini termasuk jenis penelitian analisis deskriptif dengan analisis data kualitatif. Pengumpulan data dilakukan dengan metode tes dan wawancara yang dilakukan sebanyak dua kali yaitu TPM 1 dan TPM 2. Subjek penelitian diambil 2 mahasiwa dari 35 mahasiwa angkatan 2016, terdiri dari satu mahamahasiswa laki-laki dan satu mahamahasiswa perempuan. Mahamahasiswa tersebut memiliki kemampuan matematika tinggi. Setiap subjek penelitian diwawancarai terkait hasil pekerjaannya pada TPM 1. Untuk mendapatkan kredibilitas data dilakukan tes kedua, yang artinya penelitian ini menggunakan triangulasi waktu. Selanjutnya, data dianalisis untuk mengetahui jenis kesalahan mahamahasiswa berdasarkan analisis Newman. Berdasarkan hasil penelitian, diperoleh data bahwa semua subjek penelitian tidak melakukan kesalahan membaca, kesalahan memahami masalah, kesalahan transformasi dan kesalahan penulisan jawaban. Akan tetapi, semua subjek penelitian melakukan kesalahan kemampuan proses baik pada TPM 1 maupun pada TPM 2. Subjek mahamahasiswa laki-laki melakukan kesalahan karena tidak mengetahui cara- cara yang tepat dalam menggunakan rumus yang ada. Sedangkan, subjek mahamahasiswa perempuan melakukan kesalahan karena kurang memahami konsep eksponen serta kebingungan ditengah operasi matematis.
\end{abstract}

Kata kunci: analisis kesalahan mahasiswa, masalah, struktur aljabar, analisis Newman, gender

\begin{abstract}
Difficulties in learning are caused by student study programs in mathematics education to solve problems in solving mathematics. The mistake was made by both male and female students. In the course, algebraic structure is one of the material that requires the right procedure in its completion. This research includes descriptive analysis with qualitative data analysis. Data collection was carried out by test and interview methods conducted twice, namely TPM 1 and TPM 2. Subjects were considered as 2 students from 35 students of class 2016, consisting of one male student and one female student. The student has high mathematical skills. Each research subject was interviewed regarding the results of his work at TPM 1 . To find the
\end{abstract}


credibility of the data, the second test was conducted, which means that this study uses time triangulation. Furthermore, the data were analyzed to determine the types of student errors according to Newman's analysis. Based on the results of the study, data obtained that all research subjects did not make mistakes, errors, errors and answer errors. However, all research subjects made a mistake in the process at TPM 1 or at TPM 2. The male student subject made a mistake because he did not know the right way to use the existing formula. Meanwhile, female student subjects made mistakes because they did not understand the concept of exponents and chaos amid mathematical operations

Key words: analysis of student errors, problems, algebraic structure, Newman's analysis, gender

\section{PENDAHULUAN}

Pembelajaran yang dilakukan saat ini tidak lagi harus berpusat pada dosen, tetapi lebih diarahkan pada mahasiswa, dimana mahasiswa harus mengontruksikan sendiri pemahamannya. Dosen hanya bertindak sebagai fasilitator dalam pembelajaran, sehingga terjadi perubahan paradigma mengajar ke paradigma belajar sesuai dengan paham kontruktivisme. Proses pembelajaran juga perlu dilihat, dievaluasi, diperbaiki, bahkan ditingkatkan tentang kualitas proses dan hasil pembelajaran matematika.

Hal tersebut dilakukan agar kesulitan belajar matematika yang terjadi dan dialami mahasiswa pada mata kuliah struktur aljabar tertentu dapat dianalisis dan dicari solusi/pemecahannya. Solusi yang diberikan diharapkan akan merubah perilaku dan hasil belajar matematika mahasiswa.
Menurut Tadda (2012) proses pembelajaran di kelas banyak melibatkan mahasiswa, baik mahasiswa laki- laki maupun mahasiswa perempuan, dimana setiap mahasiswa memiliki kesempatan yang sama untuk memperoleh informasi tentang materi yang dijelaskan dosen. Mahasiswa laki-laki dan mahasiswa perempuan berbeda secara biologis, dan perbedan itu terlihat jelas pada alat reproduksi. Perbedaan tersebut disebabkan oleh adanya hormon yang berbeda antara laki- laki dan perempuan. Adanya perbedaan ini berakibat pada perlakuan yang berbeda terhadap laki-laki dan perempuan. Selain faktor biologis, faktor lain yang mempengaruhi prestasi belajar mahasiswa adalah faktor psikologis. Secara psikologis lakilaki dan perempuan berbeda, terkait dengan intelegensi, perhatian, motivasi, minat, bakat, kematangan, dan kesiapan. Perbedaan ini membuat proses 
berpikir antara mahasiswa lakilaki dan mahasiswa perempuan mengalami perbedaan pula dalam proses pemecahan masalah matematika. Oleh karena itu, dosen dituntut untuk mengkaji lebih dalam mengenai perbedaan ini, atau lebih dikenal dengan istilah perbedaan gender.

Menurut Santrock (2007: 99), anak laki-laki sedikit lebih baik dibandingkan dengan anak perempuan dalam matematika dan sains. Secara umum, mahasiswa laki-laki sama dengan mahasiswa perempuan, akan tetapi mahasiswa laki-laki mempunyai daya abstraksi yang lebih baik daripada mahasiswa perempuan sehingga memungkinkan mahasiswa laki-laki lebih baik daripada mahasiswa perempuan dalam bidang matematika,karena pada umumnya matematika berkenaan dengan pengertian yang abstrak. Zhu (2007: 192) mengemukakan bahwa ada banyak faktor yang membuat adanya perbedaan gender dalam proses pemecahan masalah matematika, salah satunya adalah cognitive abilities. Perbedaan gender dalam pemecahan masalah matematika dapat menjadi indikasi adanya kesulitan berbeda yang dialami mahasiswa laki-laki maupun perempuan. Secara umum Mustamin Anggo (2011) menyebutkan bahwa mahasiswa mengalami kesulitan dalam memecahkan masalah matematika kontekstual antara lain disebabkan oleh ketikdakmampuan mahasiswa dalam menerjemahkan situasi kontekstual dari masalah yang dipecahkan ke dalam model matematika formal. Adanya kesulitan ini berdampak pada kesalahan-kesalahan mahasiswa dalam pemecahan masalah matematika kontekstual dalam hal ini soal cerita matematika akan terus berkelanjutan.

Kesalahan yang dilakukan mahasiswa dalam memecahkan masalah matematika dapat menjadi petunjuk sejauh mana penguasaan mahasiswa terhadap materi. Dari kesalahan yang dilakukan mahasiswa laki-laki dan mahasiswa perempuan tersebut dapat diteliti lebih lanjut mengenai kesalahan-kesalahan mahasiswa tersebut. Kesalahan- kesalahan yang dilakukan mahasiswa harus mendapat pemecahan yang tuntas. Pemecahan masalah dilakukan dengan cara menganalisis jenis kesalahan mahasiswa dalam mengerjakan soal cerita pada materi persamaan dan fungsi kuadrat. Terdapat banyak metode analisis kesalahan mahasiswa dalam menyelesaikan masalah matematika berbentuk soal cerita. Namun, dalam penelitian ini metode yang digunakan untuk menganalisis kesalahan tersebut adalah dengan menggunakan metode analysis Newman. Metode analisis Newman diperkenalkan oleh Anne Newman pada tahun 
1977. Newman menyarankan lima kegiatan yang dapat membantu yang dapat membantu menemukan kesalahan yang dilakukan mahasiswa ketika menyelesaikan masalah matematika. Newman (dalam White, 2005) mengemukakan bahwa setiap mahasiswa yang ingin menyelesaikan masalah matematika, mereka harus bekerja melalui lima langkah berikut, yaitu membaca (reading), memahami (comprehension), mentransformasi (transformation), melakukan proses penyelesaian (process skill), dan melakukan penulisan jawaban akhir (encoding).

Berdasarkan uraian di atas, permasalahan mengenai jenis kesalahan mahasiswa baik laki-laki maupun perempuan dalam memecahkan masalah matematik pada materi persamaan dan fungsi kuadrat sangatlah menarik bagi peneliti, sehingga peneliti mengkaji lebih lanjut mengenai jenis kesalahan yang dialami mahasiswa laki-laki dan mahasiswa perempuan dalam menyelesaikan masalah matematika kontekstual berdasarkan analisis Newman.

\section{METODE PENELITIAN}

Penelitian ini dilaksanakan di IKIP Budi Utomo Malang, yang dilaksanakan pada mahasiswa angkatan 2016A. Penelitian ini termasuk jenis penelitian analisis deskriptif dengan analisis data kualitatif yang data utama berupa kata-kata yang dirangkai menjadi kalimat. Penelitian analisis deskriptif adalah penelitian yang berusaha untuk mendeskripsikan suatu keadaan, suatu kondisi secara ilmiah (Sulthon, 2012:80). Masalah-masalah yang diamati dalam penelitian ini adalah kesalahan jawaban mahasiswa dalam memecahkan masalah matematika dalam pembuktian grup berdasarkan analisis Newman. Jadi pengamatan dilakukan terhadap hasil kerja mahasiswa. Dengan demikian penelitian ini menggunakan pendekatan kualitatif.

Subjek dalam penelitian ini adalah mahasiswa IKIP Budi Utomo Malang angkatan 2016A yang akan dikelompokkan menurut gender. Pedoman pengelompokan mahasiswa berdasarkan gender adalah melalui analisis kesalahan pada pemberian soal tes berbentuk soal cerita dengan kriteria subjek yang akan diambil yaitu subjek laki-laki dan subjek perempuan. Berdasarkan hasil diskusi dengan dosen mata kuliah struktur aljabar, maka dilakukan pemilihan subjek penelitian dengan pertimbangan: (1) subjek telah mendapat materi grup; (2) masing-masing subjek masuk dalam kategori kemampuan awal matematika tinggi, sedang, atau rendah; (3) mahasiswa kelas 2016A yang sudah memiliki 
pengalaman belajar yang cukup pada materi grup namun memiliki kesalahan dalam menyelesaikan bilangan bulat sehingga diharapkan memberikan data yang akurat bagi peneliti; (4) memiliki komunikasi yang baik secara lisan sehingga lebih mudah diwawancarai untuk memperoleh data akurat yang dibutuhkan peneliti; (5) tidak adanya keterpaksaan dari mahasiswa. Teknik pemilihan subjek dilakukan berdasarkan saran dari dosen mata pelajaran. Dari hasil pemilihan subjek, ditentukan sebanyak dua subjek yaitu satu subjek laki-laki dan satu subjek perempuan. Alternatif yang yang digunakan dalam memilih subjek penelitian yaitu subjek yang dipilih masing- masing dalam kategori kemampuan tinggi, atau masingmasing subjek dalam kategori kemampuan sedang, dan atau masing-masing subjek dalam kategori kemampuan rendah. Instrumen yang digunakan dalam penelitian ini berupa instrumen utama yaitu peneliti sendiri dan instrumen pendukung seperti draft tes, pedoman wawancara dan alat perekam suara.

Pengumpulan data dilakukan di luar jam sekolah dengan waktu yang diatur bersama subjek penelitian. Pengumpulan data dalam penelitian ini dilakukan melalui pemberian soal berbentuk soal cerita (TPM) dan dilanjutkan dengan wawancara terhadap masing-masing subjek penelitian. Penyelesaian soal berbentuk soal cerita yang ditulis mahasiswa merupakan data komunikasi matematika tertulis mahasiswa, dan wawancara memberikan kesempatan mahasiswa untuk menjelaskan pemecahan masalahnya dan bagaimana ia melakukan kesalahan. Selain itu, wawancara juga digunakan untuk memperoleh informasi baru yang mungkin tidak diperoleh saat TPM. Wawancara dalam penelitiaini mengacu pada pedoman wawancara yang berupa pertanyaan-pertanyaan yang diajukan dengan harapan memperoleh data yang memadai tentang kesalahan dalam menyelesaikan soal berbentuk soal cerita menurut analisis Newman. Untuk memeriksa keabsahan data dari pemberian soal berbentuk soal cerita dan wawancara dalam penelitian ini, maka dilakukan triangulasi. Sugiono (2010:274) membedakan triangulasi menjadi tiga jenis, yaitu triangulasi sumber, teknik, dan waktu. Triangulasi dalam penelitian ini menggunakan triangulasi waktu. Menurut Sugiono (2010:274) waktu seringkali mempengaruhi kredibilitas data. Data yang dikumpulkan dengan teknik wawancara pada saat narasumber masih segar, akan memberikan data yang lebih valid sehingga lebih kredibel. Pada penelitian ini, dilakukan pengumpulan data 
sebanyak dua kali. Jarak antara pengumpulan data pertama dan data kedua adalah satu minggu. Menurut Agustin (2013:55) data yang diperoleh kemudian dibandingkan. Data dikatakan valid jika ada konsistensi atau kesamaan pandangan antara data pertama dan data kedua. Jika data yang diperoleh belum valid, maka dilakukan pengumpulan data berulangkali sampai data yang diperoleh valid. Selanjutnya data yang valid digunakan dalam penelitian. Ngongo (2016:48), proses analisis data dalam penelitian ini dilakukan dengan langkah- langkah: (1) reduksi data, (2) penyajian data, dan (3) menarik simpulan atau verifikasi.

Reduksi data adalah suatu bentuk analisis yang menajamkan, menggolongkan, mengarahkan, membuang data yang tidak perlu, dan mengorganisasi data dengan cara sedemikian rupa sehingga kesimpulan finalnya dapat ditarik dan diverifikasi. Kegiatan ini mengarah kepada proses menyeleksi, memfokuskan, menyederhanakan, dan mengabstraksikan serta mentransformasikan data mentah yang ditulis pada catatan lapangan yang dibarengi dengan perekaman. Tahap reduksi data dalam penelitian ini adalah sebagai berikut. (a) Mengoreksi hasil pekerjaan mahasiswa, yang kemudian digunakan untuk menentukan mahasiswa yang akan dijadikan sebagai subjek penelitian. (b) Hasil pekerjaan mahasiswa yang menjadi subjek penelitian yang merupakan data mentah ditransformasikan pada catatan sebagai bahan untuk wawancara. (c) Hasil wawancara disederhanakan menjadi susunan bahasa yang baik dan rapi, kemudian ditransformasikan ke dalam catatan.

Penyajian data adalah sekumpulan informasi tersusun yang memberi kemungkinan penarikan kesimpulan dan pengambilan tindakan. Dalam tahap ini data yang berupa hasil pekerjaan mahasiswa disusun menurut urutan objek penelitian. Kegiatan ini memunculkan dan menunjukkan kumpulan data atau informasi yang terorganisasi dan terkategori yang memungkinkan suatu penarikan kesimpulan atau tindakan. Tahap penyajian data dalam penelitian ini adalah sebagai berikut. (a) Menyajikan hasil pekerjaan mahasiswa yang dijadikan bahan untuk wawancara. (b) Menyajikan hasil wawancara yang telah direkam. Dari hasil penyajian data (pekerjaan mahasiswa dan hasil wawancara) dilakukan analisis, yang kemudian menghasilkan data temuan sehingga mampu menjawab permasalahan dalam penelitian ini.

Menarik simpulan atau verifikasi adalah sebagian dari satu kegiatan dari konfigurasi yang utuh sehingga mampu menjawab 
pertanyaan penelitian dan tujuan penelitian. Dengan cara membandingkan hasil pekerjaan mahasiswa dan hasil wawancara maka dapat ditarik kesimpulan letak dan penyebab kesalahan.

\section{HASIL DAN PEMBAHASAN}

Setelah istrumen soal dinyatakan valid, lalu dilakukan tes angkatan 2016 A terdiri dari 35 mahasiswa. Soal tes yang digunakan dalam penelitian berupa soal uraian sebanyak dua butir yaitu satu butir soal untuk TPM 1 dan satu butir soal untuk TPM 2. Uji coba dilaksanakan pada pertemuan ke 3 untuk TPM 1 dan pertemuan ke 4 untuk TPM 2 dengan waktu pengerjaan 30 menit. Berdasarkan nilai tes mahasiswa diperoleh data secara individu dimana dari 38 mahasiswa masih banyak yang mengalami kesalahan dalam memecahkan masalah matematika berbentuk soal cerita materi persamaan dan fungsi kuadrat. Dari hasil tes tersebut peneliti melakukan analisis. Dari hasil analisis 35 mahasiswa ini kemudian diambil masing-masing satu mahasiswa laki-laki dan satu mahasiswa perempuan untuk dijadikan subjek penelitian. Dua mahasiswa tersebut adalah mahasiswa dengan kemampuan matematika tinggi. Dari hasil analisis jawaban mahasiswa di ketahui terdapat kesalahan membaca (reading error), kesalahan memahami masalah (comprehension error), kesalahan transformasi (transformation error), kesalahan kemampuan proses (process skill error), dan kesalahan penulisan jawaban (encoding error).

Secara keseluruhan dapat dilihat bahwa dua subjek penelitian, baik subjek mahasiswa laki- laki (SL) maupuan subjek mahasiswa perempuan (SP) melakukan kesalahan pada pengerjaan soal yang diberikan. Kesalahan yang dilakukan masingmasing subjek penelitian terjadi dalam tahap yang sama tetapi memiliki perbedaan kemampuan proses. Penyebab kesalahan yang dilakukan oleh masing-masing subjek penelitian juga berbeda. Penyebab kesalahan yang dimaksud seperti kurang paham menggunakan operasi bilangan bulat modulo. Berikut adalah pembahasan untuk jenis kesalahan dan penyebabnya yang dilakukan subjek penelitian.

\section{Membaca}

Jenis kesalahan membaca terjadi jika subjek penelitian tidak membaca kata-kata ataupun symbol yang terdapat dalam soal. Berdasarkan analisis Newman dalam pemecahan masalah matematika pada tahap pertama yaitu tahap membaca, tidak ada satupun subjek yang melakukan kesalahan dalam membaca. Hal ini dapat diketahui pada saat 
wawancara. Semua subjek penelitian, baik dari subjek mahasiswa laki-laki (SL) maupun subjek mahasiswa perempuan (SP) dapat membaca soal dengan benar tanpa adanya kesalahan dalam pelafalan.

\section{Memahami Masalah}

Jenis kesalahan memahami masalah terjadi jika subjek penelitian melakukan kesalahan dalam memaknai masalah apa yang harus diselesaikan dalam soal atau tujuan akhir dari soal setelah ia mampu membaca soal. Jenis kesalahan memahami masalah menyebabkan subjek penelitian melakukan kesalahan berdasarkan analisis Newman. Penelitian ini tidak menemukan kesalahan memahami masalah terhadap subjek penelitian baik pada subjek mahasiswa laki-laki (SL) maupun pada subjek mahasiswa perempuan (SP). Semua subjek penelitian bisa memahami masalah dengan menuliskan atau menyebutkan hal-hal yang diketahui dari soal dan hal- hal apa yang akan diselesaikan.

\section{Transformasi}

Jenis kesalahan transformasi dapat terjadi jika subjek penelitian salah dalam memilih pendekatan atau rumus yang akan digunakan untuk memecahkan masalah yang diberikan setelah mampu membaca dan memahami masalah dengan benar. Dalam penelitian ini tidak ditemukan subjek penelitian yang melakukan kesalahan transformasi. Subjek penelitian mampu membaca soal dan memahami masalah sesuai yang dimaksud dalam soal, sehingga mereka dapat memilih transformasi yang tepat. Semua subjek penelitian dapat menuliskan atau menyebutkan rumus yang akan digunakan dengan tepat.

\section{Kemampuan proses}

Jenis kesalahan kemampuan memproses terjadi jika subjek penelitian salah dalam proses perhitungan setelah mereka mampu membaca, memahami masalah, dan memilih transformasi dengan benar. Jenis kesalahan kemampuan memproses berbeda dengan kesalahan pada langkah kemampuan memproses. Subjek penelitian dapat disebut melakukan jenis kesalahan kemampuan memproses jika dia memang telah mampu membaca, memahami masalah dan memilih transformasi dengan benar sesuai dengan apa yang dimaksud oleh soal lalu salah dalam proses perhitungan atau salah secara matematis. Sedangkan subjek penelitian disebut melakukan kesalahan pada langkah kemampuan memproses jika memang tidak melakukan proses apapun untuk menyelesaikan soal atau kesalahan memproses yang terjadi akibat kesalahan memahami masalah. Jadi subjek penelitian pasti melakukan jenis 
$\begin{array}{lrr}\text { kesalahan } & \text { kemampuan } \\ \text { memproses } & \text { pada } & \text { langkah } \\ \text { kemampuan } & & \text { memproses, } \\ \text { sedangkan } & \text { pada } & \text { langkah } \\ \text { kemampuan } & & \text { memproses } \\ \text { kesalahannya } & \text { belum } & \text { tentu dapat }\end{array}$ disebut jenis kesalahan kemampuan memproses.

Pada penelitian ini, jenis kesalahan kemampuan proses dilakukan oleh seluruh subjek penelitian baik pada soal TPM 1 maupun pada soal TPM 2. Penyebab terjadinya kesalahan yang dilakukan SL yaitu tidak mengetahui cara-cara yang tepat dalam menggunakan rumus yang ada untuk proses matematis selanjutnya. SL langsung menafsirkan jawaban akhir dan berusaha membuktikannya ke dalam rumus bahwa jawaban tersebut benar. Sedangkan penyebab terjadinya kesalahan yang yang dilakukan SP yaitu tidak memahami dengan baik konsep operasi bilangan bulat modulo serta kebingungan ditengah operasi matematis. SP tidak mengetahui apa yang akan dilakukan selanjutnya untuk mencapai jawaban akhir sesuai yang diinginkan soal.

\section{Penulisan jawaban}

Jenis kesalahan penulisan jawaban terjadi jika subjek penelitian salah dalam menuliskan jawaban akhir setelah mereka mampu membaca, memahami masalah, memilih transformasi dan melakukan kemampuan memproses dengan benar. Jenis kesalahan penulisan jawaban berbeda dengan kesalahan pada langkah penulisan jawaban. Subjek penelitian dapat disebut melakukan jenis kesalahan penulisan jawaban jika dia memang telah mampu membaca, memahami masalah, memilih transformasi dan melakukan kemampuan memproses dengan benar sesuai dengan apa yang dimaksud oleh soal lalu salah dalam menuliskan jawaban karena kekurang telitian. Sedangkan subjek penelitian disebut melakukan kesalahan pada langkah penulisan jawaban jika memang tidak ada jawaban atau respon apapun untuk menanggapi soal. Jadi subjek penelitian pasti melakukan jenis kesalahan penulisan jawaban pada langkah penulisan jawaban, sedangkan pada langkah penulisan jawaban kesalahannya belum tentu dapat disebut jenis kesalahan penulisan jawaban.

Pada penelitian ini, jenis kesalahan penulisan jawaban dilakukan oleh semua subjek penelitian. Mereka melakukan kesalahan pada langkah penulisan jawaban. Subjek mahasiswa lakilaki (SL) maupun subjek siawa perempuan (SP) melakukan kesalahan akibat jenis kesalahan sebelumnya yaitu kesalahan kemampuan proses, yang walaupun kesalahan kemampuan proses yang dilakukan berbeda 
langkah dan cara matematis. Cara matematis yang dimaksud adalah cara dalam mengaplikasikan rumus yang ada.

Penjelasan lebih lanjut mengenai kesalahan yang dilakukan subjek penelitian dalam memecahkan masalah matematika materi grup jenis 1 , jenis 2, dan jenis 3 yaitu kesalahan membaca, kesalahan memahami masalah dan kesalahan transformasi. Jenis kesalahan selanjutnya adalah kesalahan jenis 4 yang merupakan jenis kesalahan yang dilakukan oleh semua subjek penelitian yaitu kesalahan kemampuan memproses. Karena seluruh subjek penelitian melakukan kesalahan pada langkah-langkah sebelumnya, maka menurut analisis Newman subjek penelitian tersebut tidak melakukan kesalahan penulisan jawaban.

\section{KESIMPULAN DAN SARAN}

Berdasarkan hasil penelitian yang dilakukan, maka dapat diambil kesimpulan. Jenis kesalahan yang dilakukan mahasiswa memecahkan masalah matematika materi persamaan dan fungsi kuadrat ditinjau dari gender berdasarkan analisis Newman adalah sebagai berikut, (1) Semua subjek penelitian baik subjek mahasiswa laki-laki maupun subjek mahasiswa perempuan tidak melakukan kesalahan jenis kesalahan membaca. Hal itu dapat dilihat dari kemampuan mahasiswa ketika membaca soal dengan baik dan benar. (2) Semua subjek penelitian baik subjek mahasiswa laki-laki maupun subjek mahasiswa perempuan tidak melakukan kesalahan jenis kesalahan memahami masalah. Hal itu dapat dilihat dari kemampuan mahasiswa dalam menuliskan/ menyebutkan hal-hal yang diketahui dari soal dan masalah apa yang akan dicari penyelesaiannya. (3) Semua subjek penelitian baik subjek mahasiswa laki- laki maupun subjek mahasiswa perempuan tidak melakukan kesalahan jenis kesalahan transformasi. Hal itu dapat dilihat dari kemampuan mahasiswa dalam menuliskan/menyebutkan rumusrumus yang akan digunakan dalam memecahkan masalah yang diberikan. (4) Semua subjek penelitian melakukan jenis kesalahan kemampuan proses, baik pada TPM 1 maupun TPM 2. Subjek mahasiswa laki-laki melakukan kesalahan karena tidak mengetahui cara-cara yang tepat dalam menggunakan rumus yang ada untuk proses matematis selanjutnya. Sedangkan, subjek mahasiswa perempuan melakukan kesalahan karena tidak memahami dengan baik serta kebingungan ditengah operasi matematis. (5) Semua subjek penelitian baik subjek mahasiswa laki-laki maupun subjek mahasiswa 
perempuan tidak melakukan kesalahan jenis kesalahan penulisan jawaban.

Berdasarkan hasil penelitian yang dilakukan, maka diberikan saran sebagai berikut: (1) Untuk mahasiswa, diharapkan agar mahasiswa rajin belajar dan melatih diri dalam memecahkan masalah matematika sehingga tidak terjadi kesalahan-kesalahan dan selalu mempelajari kembali materi- materi sebelumnya, karena materi tersebut berkaitan dengan materi selanjutnya. (2) Untuk dosen, agar mahasiswa terhindar dari kesalahan kemampuan proses, dosen hendaknya memastikan kembali bahwa mahasiswa benar-benar sudah memahami masalah yang harus diselesaikan dan juga transformasi yang digunakan sudah tepat. Jika masalah yang dipahami benar dan transformasi yang digunakan tepat, kemungkinan langkah kemampuan memproses mereka juga tidak akan terlalu melenceng dari prosedur. Dosen perlu lebih banyak memberikan latihan soal berbentuk soal cerita yang menekankan pada penerapan rumus dan menekankan pemahaman konsep secara jelas dalam melakukan proses pembelajaran serta perlu mengaktifkan mahasiswa di dalam kegiatan pembelajaran, terutama bagi mahasiswa yang mengalami kesulitan dalam belajar. Dosen dapat menggunakan prosedur
Newman untuk menganalisis kesalahan peserta didik dalam memecahkan masalah matematika tidak hanya pada materi persamaan dan fungsi kuadrat saja, tetapi juga pada materi yang lain. (3) Untuk sekolah, diharapkan agar hasil penelitian ini bisa menjadi pedoman untuk meningkatkan prestasi belajar mahasiswa dan memfasilitasi dosen dalam melaksanakan pembelajaran. Alat dan bahan yang dibutuhkan dosen harus tersedia sehingga proses pembelajaran menjadi lancar dan mahasiswa lebih nyaman menerima pelajaran dari dosen. (4) Untuk pembaca, diharapkan agar hasil penelitian ini bisa menjadi pedoman dalam pengembangan ilmu dan penelitian-penelitian selanjutnya.

\section{DAFTAR PUSTAKA}

Agustin, Ririn Dwi. 2013. Profil Pemahaman Mahasiswa Calon Guru dalam Memecahkan Masalah Pembuktian Geometri ditinjau dari Gaya Kognitif Reflektif dan Impulsif. Tesis Unesa Surabaya: Tidak diterbitkan.

Mustamin, Anggo. 2011. Pemecahan Masalah Matematika Kontekstual untuk Meningkatkan Kemampuan Metakognisi Mahasiswa. Edumatika, $1(2)$.

Ngongo, Martinus Dowa. 2016. Analisis Kesalahan Mahasiswa Berdasarkan 
Kategori Kesalahan Watson dalam Menyelesaikan Soal Barisan dan Deret Bilangan di SMP Rangga Rame Tahun Pelajaran 2016/2017. Skripsi IKIP Budi Utomo Malang: Tidak diterbitkan.

Santrock, J. W. 2007. Child Development,

Perkembangan Anak, Edisi ke-7, Jilid 2. Jakarta: Erlangga.

Sugiyono. 2009. Metode Penelitian Pendidikan (Pendekatan Kuantitatif, Kualitatif, dan $R$ $\& D)$. Bandung: IKAPI.

Sulthon, Masyhud. 2012. Metode Penelitian Pendidikan Edisi 3, Cetakan ke 1. Jember: Lembaga Pengembangan Manajemen dan Profesi Kependidikan (LPMPK).

Tadda, Marhamah. Analisis Kesalahan Mahasiswa dalam Menyelesaikan SoalSoal Aljabar Berdasarkan Gender. Palopo: Prosiding Seminar Nasional. Vol. 02, 347-354.

White, A. L. 2005. Active Mathematics in Classrooms: Finding out why children make mistakes and then doing something to help them. University of Western Sidney.

Zhu. 2007. Gender Differences in Mathematical Problem Solving Patterns: a Review ofliterature. International Education Journal / Vol. 8 No. 187-203. 